
VACAS HOLSTEIN E BLACK-MOTLEY

\title{
MILK PRODUCTIVITY AND TECHNOLOGICAL PROPERTIES OF THE MILK FROM THE HOLSTEIN AND BLACK-MOTLEY COWS
}

\section{МОЛОЧНАЯ ПРОДУКТИВНОСТЬ И ТЕХНОЛОГИЧЕСКИЕ СВОЙСТВА МОЛОКА КОРОВ ГОЛШТИНСКОЙ И ЧЁРНО-ПЁСТРОЙ ПОРОД}

\author{
BABICH, Elena Anatolyevna ${ }^{*}$; OVCHINNIKOVA, Lyudmila Yuryevna2; OVCHINNIKOV, \\ Aleksandr Aleksandrovich ${ }^{3}$; ZHAKSUMBAY, Zhanara Serikovna ${ }^{4}$ \\ ${ }^{1,4}$ Kostanay Research Institute of Agriculture. Kazakhstan. \\ ${ }^{2,3}$ South Ural State Agrarian University, Institute of Veterinary Medicine. Russian Federation. \\ ${ }^{*}$ Correspondence author \\ e-mail: elena._76@mail.ru
}

Received 12 June 2020; received in revised form 30 September 2020; accepted 28 October 2020

\section{RESUMO}

Ao avaliar vacas leiteiras, tanto as propriedades quantitativas quanto tecnológicas do leite são essenciais. Os conteúdos de matéria seca e de sólidos não gordurosos do leite determinam o valor nutricional do leite e do seu consumo para obter produtos lácteos. $\mathrm{O}$ artigo apresenta um estudo das características do leite de vacas das raças Holstein e black-motley. O estudo buscou determinar a adequação do leite para a produção de queijo. No experimento científico e econômico, as propriedades tecnológicas do leite das vacas Holstein e black-motley, com vários níveis de produtividade leiteira, foram comparativamente analisadas. Com base nos resultados dos estudos, descobriu-se que, com um alto nível de produtividade leiteira, o leite das vacas Holstein continha $12.4 \%$ menos matéria seca e que o leite das vacas black-motley continha $10.9 \%$ menos matéria seca. O aumento do conteúdo de matéria seca resultou em um aumento geral do conteúdo de gordura e de proteína para $93.0 \%$ e $87.1 \%$, respectivamente. Uma correlação predominantemente positiva entre os componentes do leite foi encontrada. Para a produção de queijo, o leite de vaca com uma concentração maior de matéria seca é o mais valioso. A venda do leite com base no seu conteúdo de matéria seca permite que uma economia obtenha uma receita US $\$ 3.07$ maior para a raça Holstein e US\$1.90 maior para a raça black-motley.

Palavras-chave: proteína, lactose, caseína, proteínas do soro, eficiência econômica.

\section{ABSTRACT}

In assessing dairy cows, both quantitative and technological milk properties are essential. The contents of dry matter and nonfat milk solids determine the nutritional value of milk and its consumption for obtaining dairy products. The article presents a study of the characteristics of milk from cows of Holstein and black-motley breeds. The study aimed to determine the suitability of milk for cheese making. In the scientific and economic experiment, the technological properties of the milk from the Holstein and black-motley cows with various levels of milk productivity were comparatively analyzed. By the results of the studies, it has been found that with a high level of milk productivity, the milk of the Holstein cows contained less dry matter by $12.4 \%$, and the milk of black-motley cows contained less dry matter by $10.9 \%$. Increasing the content of dry matter has resulted in overall increasing fat and protein content to $93.0 \%$ and $87.1 \%$, respectively. A predominantly positive correlation between the milk components has been found. For cheese-making, cow milk with a higher concentration of dry matter is the most valuable. The milk sale by its dry matter content allows an economy to obtain more revenue by USD 3.07 for the Holstein breed and by USD 1.90 for the black-motley breed.

Keywords: protein, lactose, casein, whey proteins, economic efficiency.

\section{АННОТАЦИЯ}

При оценке коров молочных пород важное значение имеют не только количественные, но и 
технологические показатели молока. Показатели сухого вещества и СОМО обуславливают питательную ценность молока, его расход при производстве молочных продуктов. В статье приведены результаты исследования характеристик молока коров голштинской и чёрно-пёстрой породы. Целью исследования было определение пригодности молока для сыроделия. В научно-хозяйственном опыте проведен сравнительный анализ технологических свойств молока коров голштинской и чёрно-пёстрой породы разного уровня молочной продуктивности. По результатам исследований установлено, что при высоком уровне молочной продуктивности в молоке коров обеих пород содержалось меньше сухого вещества на $12,4 \%$ по голштинской и 10,9\% по чёрно-пёстрой породе. Увеличение сухого вещества обусловило суммарное повышение содержания жира и белка 93,0\% и 87,1\% соответственно. Определена преимущественно положительная корреляционная связь между составными частями молока. Наиболее ценным для сыроделия является молоко коров с большей концентрацией сухого вещества. Реализация молока по содержанию сухого вещества позволяет хозяйству получать больше выручки на 3.07 доллара по голштинской породе и 1.90 доллара по черно-пестрой породе.

Ключевые слова: белок, лактоза, казеин, сывороточные белки, экономическая эффрективность.

\section{INTRODUCTION:}

In all countries of the world, 652 breeds of cattle are currently bred, including about 30 breeds of various productivity orientations in Kazakhstan. Breeding so many breeds is explained by the fact that one or two breeds will not completely and optimally use various forage and climatic conditions in individual zones of this vast country. Among the indicators that characterize the biological, breeding, and productive qualities of breed or crossbred cattle, milk productivity and milk composition are important features. Depending on the main components in milk, cattle breeds differ against each other and are divided into rich-milking and so-called curd breeds, the milk of which is the richest in protein. Along with the task of increasing milk productivity, modern cattle breeding is facing the task of substantially improving milk quality, which means a combination of various properties, depending on the purpose (Babich, Kikebaev, Raketskiy, and Baysakalov, 2019; Katmakov, Gavrilenko, Bushov, and Prokofiev, 2019). The prospects of the development of dairy cattle breeding and the future of the dairy industry in Kazakhstan are mainly associated with the production of highquality raw milk and its further processing into high-quality dairy products. In particular, ensuring the nutritional value of foodstuffs requires increasing the share of animal proteins, where a significant role is played by the milk protein, which has high biological value (Safronova, Babich, Ovchinnikova, Ovchinnikov, 2017; Babich, Nugmanov, Ovchinnikova, and Ovchinnikov, 2016). Milk proteins enter the human organism with milk, dairy products, and cheese. This causes redistribution in the structure of milk, namely, the share of the milk consumed fresh and the one processed into butter, and condensed milk reduces, while the share of the milk processed into cheese increases. This has brought forward new demands to the milk quality and to increasing the content of all the components of dry matter, especially protein (Cole, Bickhart, Waurich, Wensch-Dorendorf, and Swalve, 2014 Adamczyk, Makulska, Jagusiakand, and Węglarz, 2017; Holroyd et al., 2002).

Milk, being the most proper food product, contains a set of all essential nutrients in an easily digestible and balanced form. Milk composition determines its biological and nutritional value and the yield and quality of dairy products. In this regard, knowledge of changes in the chemical composition of the milk from cows of various breeds during production and processing is of great importance. Milk has a complex chemical composition: the moisture content is within $87.5 \%$, the dry matter content is about $12.5 \%$. Dry matter includes fat $(3.6 \%)$, protein $(3.2 \%)$, lactose $(4.7 \%)$, minerals $(0.7 \%)$, and about 250 more components.

In the breeding work with dairy cattle, mainly the milk yield and the fat content in the milk have been taken into account for a long time. However, given the modern requirements for product quality, such an approach does not allow a comprehensive, in-depth assessment of milk productivity. The most valuable milk is the dry matter, which consists of fat, proteins, milk sugar, minerals, vitamins, pigments, hormones, enzymes, and immune bodies with high biological activity. Nonfat milk solids and lactose should also be taken into account. In the human organism, lactose plays an energetic role and creates a favorable environment for developing beneficial microflora.

Improving the quality and composition of produced raw milk remains relevant since making any type of dairy products requires raw materials compliance with several indicators. Therefore, the traditional traits of dairy cattle breeding have been 
recently supplemented with the content of milk, protein, lactose, nonfat milk solids (NFMS), dry matter, and the total content of fat and protein (De Jong, 2000; Bastin, Loker, Gengler, Sewalem, and Miglior, 2010; Pimentel, Erbe, Knig, and Simianer, 2011; Wang, Segelke, Emmerling, Bennewitz, and Wellman, 2017). The purchase price for milk is also set by processing enterprises with consideration of the indicators set above.

\subsection{Literature Review:}

When the economic and social conditions in agricultural production have fundamentally changed, real opportunities have opened up for the accelerated intensification of dairy cattle breeding.

The basis for increasing the efficiency of dairy cattle breeding and improving the productive qualities is improving the breeding work. The analysis of the previous stages of work showed the gradually increasing intensification pace, which had been primarily caused by introducing the new biotechnological methods, the population genetics, and the use of the world's best gene pool of the dairy breeds.

In the leading countries, the intensification of dairy cattle breeding is ensured by increasing highly productive breeds, especially the Holstein one. Conditions are created for the maximum possible introduction and long-term use of the genotype. The high productivity of the cows and improving their reproductive abilities and longterm economic use are achieved only through the full-fledged feeding and balancing of the diets in terms of the content of all the necessary nutrition elements, creating comfortable conditions for animals, and high-productive work of the personnel. As a rule, on average, highly productive animals give better offsprings characterized by the growth and development energy, and, finally, valuable dairy traits. Some authors note that the most important factor affecting milk composition and quality is the breed features of the animals.

In assessing the productive qualities of the dairy cows, the following features were used: the milk yield obtained over 305 days of lactation, the peak daily milk yield, the uniformity of lactation, the milk flow intensity, the completeness of milking, and the content of fat, protein, and NFMS (Yesbolova and Maciejczcak, 2012; Samusenko and Khimicheva, 2018).

The main task in dairy farming is intensifying the industry by accelerating the growth of the genetic potential of domestic cattle and the degree of its implementation. To increase the milk productivity of motley-black cows, several commercial farms throughout the country engaged in breeding use the Holstein breed gene pool, which gives a powerful impetus to the development of the entire dairy cattle breeding. This breed occupies one of the leading places in terms of the milk productivity ratio to the operation of industrial complexes.

A high level of lactation causes a restructuring of the entire organism of the animal and changes the correlations between various indicators. First of all, milk productivity increases demand for qualitative milk composition (Faizullin and Kharlan, 2019; Khromova and Manzhurin, 2018; Nemtseva and Ignatieva, 2020).

A comparative assessment of the productivity and quality of the milk obtained from purebred motley-black cows showed that their origin influenced milk process parameters. For instance, cows of the Ues Ideal line were characterized by better rennet coagulation, high content of casein $(2.65-2.70 \%)$, and milk sugar $(4.86 \%)$ (Gagloev, Negreeva, Gagloeva, and Skobeev, 2017).

The quality of milk is not stable and depends on several factors, one of which is targeted breeding aimed at increasing the hereditary potential in the context of the modern breed composition and interbreed groups bred in specific keeping and feeding conditions, and breeding aimed at improving the composition of the milk as an important criterion for selecting animals of specialized dairy breeds.

In the conditions of breeding farms in the Russian Federation, the Holstein breed plays a leading role. The studies of N. I. Morozova, F. A. Musaeva, O. A. Morozova (2016) performed at the breeding plant of the Avangard LLC enterprise in the Ryazan region showed that milk productivity of individual cows of the Holstein breed was higher than that of black-motley cows with year-round stall keeping in terms of milk yield by $1,140 \mathrm{~kg}$, or $16.1 \%$, the amount of milk fat - by $48.4 \mathrm{~kg}$, or $21.2 \%$.

Holstein cows are genetically related to black-motley cows but differ in their pronounced milk type, high milk productivity, and better adaptability to the machine milking technology (Tumov, 2018). They use bulky coarse fodder well and are characterized by the absence of a tendency to obesity in abundant feeding with a high share of concentrated fodder in the diet (Kuznetsov and Ireykina, 2017; Brel-Kisseleva and Safronova, 2017). 
Y. K. Tomilin, P. I. Zelenkov and V. K. Tomilin (2012) in the conditions of Imeni llyicha JSC in the Leningradsky district of the Krasnodar Krai found that cows belonging to the USA V.B. Ideal and M. Chieftain lines were superior to their peers in the milk yield by $1,194 \mathrm{~kg}$, or $22.6 \%$ and $1,079 \mathrm{~kg}$, or $20.4 \%$, respectively; the cows of the Canadian R. Sovering line - by $1,204 \mathrm{~kg}$ or $22.8 \%$.

In the conditions of Udmurtia, Holstein cows were superior to their peers of the Ayrshire breed in terms of the milk yield over 305 days of the first lactation by $10.72 \%$, and over the second lactation - by $14.30 \%$, but were inferior to the Ayrshire breed in terms of the mass fraction of fat and protein by $8.27 \%$ and $5.45 \%$ due to the breed features (Izhboldina and Nikolaeva, 2013).

The duration of Holstein animals economic use at the breeding farms in the Northern TransUrals is 2.8 lactations, and the milk productivity is $8,452 \mathrm{~kg}$ of milk with the milk fat content of $4.4 \%$, or $370 \mathrm{~kg}$ of milk fat, protein - $3.2 \%$, or $268 \mathrm{~kg}$ of milk protein (Tatarkina and Belenkaya, 2017).

Scientists believe that the effectiveness of crossing is always higher when this breed, which is characterized by stable heredity and high genetic productivity potential, is used (as the paternal breed) (Paderina, 2020).

The selection of animals by their origin is of great importance for improving the productive qualities. Many authors, in particular A. S. Karamaeva, N. V. Soboleva, S. V. Karamaev (2016; 2018), L. V. Efimova, O. A. Frolova, and T. V. Zaznobina (2018), after studying and comparing the data in the scientific literature about milk productivity of motley-black breeds in various countries in dynamics, have found that at present no breed can compete with Holstein in terms of this indicator. Therefore, in improving domestic motley-black cattle and purebred breeding, it is widely crossed with the Holstein breed (Erofeev, 2018).

V. G. Kakhikalo and O. S. Chechenikhina (2009) stated that an increase in milk productivity was preserved in the animals with increased blood relationship with the improving breed. Blood relationship management in animal breeding and acceleration of the new population's consolidation remain urgent tasks in dairy cattle breeding.

The inheritance of milk productivity and milk composition (butter-fat yielding capacity and protein yielding capacity) is independent, while milk composition is mostly determined genetically. The maximum productivity of an animal depends on certain important conditions: favorable keeping conditions, i.e., avoidance of behavior deviations; sufficient amount of milk "predecessors", i.e., complete and balanced diet; regular and fairly complete emptying of milk from the lacteous gland, i.e., complete high-quality milking (Pavlov, 2019; Pustotina and Pustotina, 2016).

A comparative assessment of the quality of the milk obtained from Holstein and black-motley cows with various milk productivity determines the relevance and the scientific and practical significance of the studies. Each breed has its characteristic features of milk composition and properties (Mkrtchyan, Bakai, and Bakai, 2020). According to most authors, the mass fraction of fat and protein in the milk from the most productive Holstein cows is rather low. For instance, with the $5,239 \mathrm{~kg}$ milk yield of full-aged cows, the content of fat and protein in the milk from Holstein cows is $3.73 \%$ and $2.95 \%$, respectively. Simultaneously, several authors provide information about a rather high mass fraction of fat in the milk from Holstein cows. In turn, milk productivity of the German Holstein heifers breed was $5,022 \mathrm{~kg}$ over 305 days of lactation with fat content in the milk of $3.96 \%$, and protein - of $3.33 \%$. Over the period from 2007 to 2017, the average milk yield of the Holstein black-motley breed had increased by $2,477 \mathrm{~kg}$, and in 2017, it amounted to $8,567 \mathrm{~kg}$ of milk, and the fat content was $3.86 \%$. The highest productive longevity of Holstein black-motley cows was noted in the North-West, the Far East, and the Volga Federal Districts. The average age of retirement there was $3.20 ; 3.18 ; 2.85$ calvings, respectively. In $36.2 \%$ of the monitored cows, the fat content in the milk ranged from 3.91 to $4.23 \%$, while in $21.8 \%$ of the cows, the fat content in the milk exceeded $4 \%$ (Firsova and Kartashova, 2019; Dunin, Tyapugin, Meshcherov, Khodykov, Mescherov, and Nikulkin, 2020; Dolgosheva, Korosteleva, and Romanova, 2018; Shushpanova and Tatarkina, 2020).

In the favorable environmental conditions, milk composition and properties depend on the genotypic characteristics of the organism, and the heritability estimates between the main milk components allow breeding following these characteristics.

In crossbreeding, it is important to preserve the high quality of the milk from improved breeds and adjust it in the proper direction by maximizing the use of the prepotent animals in this respect. Holstein cattle have the highest genetic potential in milk production and a set of qualities that ensure the best adaptability to the industrial milk production technology, which has made it a leader 
in improving domestic cattle breeds. An important direction in dairy cattle breeding is the productive longevity of cows, which is directly related to milk productivity and the process indicators of the milk, which is becoming more and more relevant (Shishkina, Nikishova, and Naumov, 2017).

Scientific and practical experience shows that the yield of the dairy products made from milk and their quality are determined by the properties of milk and depend on the breed and the animals feeding and keeping conditions. In the studies of the authors, the suitability of the milk from Holstein and black-motley cows for making cheese was studied as the process property in the comparative aspect.

\section{MATERIALS AND METHODS:}

The objects of the studies were Holstein and black-motley breeds.

Four groups of cows were formed for the studies: the first and the second groups each contained 10 Holstein cows, and the third and the fourth groups each contained 10 black-motley cows. A total of 40 cows were used in the experiment. The groups were formed regarding the milk productivity of cows over 305 days of lactation and the dry matter content in the milk. In the first group with Holstein cows, the milk yield was $5,000-5,500 \mathrm{~kg}$ over 305 days of lactation, and the dry matter content in the milk was 12.5 $13.0 \%$; in the second group, the milk yield was $5,500-6,000 \mathrm{~kg}$, and the dry matter content was $12.0-12.5 \%$. In the third group with black-motley cows, the milk yield was 4,000-4,500 kg over 305 days of lactation, and the dry matter content in the milk was 13.0 - $13.5 \%$; in the fourth group, the milk yield was $4,600-5,100 \mathrm{~kg}$, and the dry content matter was $12.5-13.0 \%$.

The milk productivity was accounted individually for each cow through monthly milk checks. For determining the milk yield per month, the milk yield for the reference days of months I, III, V, VII, IX was multiplied by 30 , and that for months II, IV, VI, VIII, X - by 31 . The milk yield over 305 days of lactation was determined by summing the milk yields for 10 months of lactation. The content of dry matter, fat, protein, lactose, and NFMS was determined using the Infra Milk automated measuring complex for milk quality analysis made by the Profi Company (manufactured in Novosibirsk, Russia, by Sibagropribor LLC). This device was also used for determining the composition of milk proteins casein and whey proteins. The analyses were performed monthly at an accredited laboratory (Accreditation Certificate No. KZ.T.11.2311) using the average milk sample taken during milk checks. The milk yield of each month was multiplied by the dry matter index of the month, and then the summed products were divided by the actual milk yield over 305 days of lactation. The quotient is the average dry matter content over 305 days of lactation. The mean values of fat, protein, lactose, and NFMS content were also determined. The content of fat + protein was found by summing fat and protein (Bezenko, 1983).

The data of the average values of milk yield, dry matter, fat, protein, lactose, fat + protein, and NFMS, $\mathrm{M} \pm \mathrm{mx}$ by groups, presented in Table 1 , were calculated using the Equations 1, 2, and 3 proposed by G.F. Lakin (1990) :

$$
\mathrm{M}=\frac{\mathrm{M} 1+\mathrm{M} 2+\mathrm{M} 3+\mathrm{M} 4+\cdots \mathrm{M} 10}{n-1},
$$

where $M$ was the average value of the indicator (milk yield, dry matter, fat, protein, lactose, fat + protein, and NFMS),

$M 1, M 2, M 3 \ldots . M 10$ were the individual values of the indicator,

$\mathrm{n}$ was the number of indicator units (the number of animals in the group).

The $\mathrm{m}$ value was determined by Equations 2 and 3 :

$$
\sigma=\sqrt{\frac{\sum(\mathrm{M} i-\mathrm{M})}{n-1}},
$$

where $\sigma$ was the standard deviation,

$M_{i}$ was each observed value of the indicator,

$M$ was the arithmetic mean,

$\mathrm{n}$ was the number of animals in the group.

And the $\mathrm{m}$ value was determined by Equation 3:

$\mathrm{m}=\frac{\sigma}{\sqrt{n}}$,

where $m$ was the statistical error of the average value of the indicator,

$\sigma$ was the standard deviation,

$\mathrm{n}$ was the number of animals in the group.

For determining the correlation dependence, the average values for each group were calculated for the 305 days of lactation: the milk yield and the dry matter, fat, protein, lactose, fat + protein, and NFMS. The correlation coefficient was expressed as a decimal fraction. 
The + or - signs indicate the direction of the correlation. In the case of positive or direct correlation, when larger values of one trait correspond to larger values of another trait, the correlation coefficient is positive and ranges from 0 to +1 ; in the case of negative or reverse correlation, when larger values of one trait correspond to smaller values of another trait, the correlation coefficient is negative and ranges from 0 to -1 .

Equation 4 was proposed by Lakin (1990) it was used to calculate the correlation coefficient $(r)$ :

$$
r=\frac{\sum x y-\frac{\sum x * \sum y}{n}}{\sqrt{a x} * a y},
$$

where ax $=\sum \mathrm{x}^{2}-\frac{\left(\sum x\right)^{2}}{n}$ and ay $=\sum \mathrm{y}^{2}-\frac{\left(\sum y\right)^{2}}{n}$; $x$ was the variants of the first trait;

$y$ was the variants of the second trait; and sample.

$\mathrm{n}$ was the number of observations in the

A simple correlation ( $r$ ) was determined between two traits: milk yield and dry matter content, fat and dry matter content, protein and dry matter content, lactose and dry matter content, fat + protein and dry matter content, NFMS and dry matter content, milk yield and fat content, protein and fat content, lactose and fat content, fat + protein and fat content, NFMS and fat content, milk yield and protein content, lactose and protein content, fat + protein and protein content, NFMS and protein content, milk yield and lactose content, fat + protein and lactose content, NFMS, and lactose content, milk yield, and fat + protein content, NFMS and fat + protein content, milk yield and NFMS content.

The Equation 5 was used to calculate the veracious value of the correlation coefficient $(\mathrm{Td})$ :

$\mathrm{Td}=\frac{\mathrm{r}-\sqrt{\mathrm{n}-2}}{\sqrt{1-\mathrm{r}^{2}}}$,

where

$r$ was the correlation coefficient;

$\mathrm{n}$ was the number of observations in the sample; and

Td was the standard value of the criterion determined according to the Student's table (Lakin, 1990).

All the experimental animals were kept in the same conditions consistent with the zoohygienic and zootechnical requirements.

\section{RESULTS AND DISCUSSION:}

With the overall high milk productivity $(4,469-5,901 \mathrm{~kg})$, the Holstein and black-motley cows, the milk of which contained less dry matter (groups II and IV), were characterized by higher milk yields, compared to their peers in groups I and III (12.4\% for the Holstein breed, and $10.9 \%$ for the black-motley breed, respectively), Table 1.

The compared groups of cows of the same breed differed in the content of dry matter: the Holstein breed - by $0.57 \%(P>0.95)$, the blackmotley breed - by $0.7 \%(P>0.99)$. Higher milk saturation with the dry matter was accompanied by a higher content of the other components, namely, fat, protein, and lactose. The highest differences in the milk composition within the same breed were noted in terms of protein, fat, and the total content of fat and protein ( $P>0.95-0.99$ ), lower and unreliable differences - in terms of NFMS, and the minimum differences - in terms of lactose. However, in the total increase of the dry matter content in the milk (100\%), the share of fat was $64.9 \%$ (the Holstein cows) and $71.4 \%$ (the blackmotley cows), the share of protein was $28.1 \%$ and $15.7 \%$, the share of lactose $-5.3 \%$ and $2.8 \%$, the share of total fat and protein $-93.0 \%$ and $87.1 \%$, and the share of NFMS - 35.1\% and $28.6 \%$, respectively. The above data showed that increasing the share of dry matter was mainly due to the total increase in fat and protein content. This was also confirmed by the established relationship between the studied productivity values of milk (Table 2).

A negative relationship was found between the milk yield and the content of the main milk components, although this relationship differed in the magnitude and the level of reliability.

The analysis of the correlations between the milk components showed that they had a predominantly positive value. Naturally, the most veracious relationship existed between the content of dry matter and other milk components, mainly the content of fat and protein. There were different levels of relationship between the content of fat and protein: it was reliable in group I, moderate in group II, virtually absent in group III, and weakly positive in group IV. The correlation between the content of fat and protein was significantly inferior to the positive relationship between each of them (fat or protein) and the content of dry matter in the milk. The relationship 
between the fat content and NFMS in the milk, although it differed in the cows in the experimental groups by both the sign and the value, was not veracious. A weak negative or positive correlation existed between the content of fat and that of protein with lactose.

Based on the observed nature of the relationship between the milk yield and the main milk components, studying their total content in the milk yield per lactation is of great interest (Table $3)$.

Table 3: The total content of the main milk components, $\mathrm{kg}$

\begin{tabular}{lllll}
\hline Indicator & $\begin{array}{l}\text { The } \\
\text { breed }\end{array}$ & Holstein & $\begin{array}{l}\text { The } \\
\text { motley breed }\end{array}$ \\
\cline { 2 - 5 } & \multicolumn{2}{l}{$\begin{array}{l}\text { Group } \\
\text { black- }\end{array}$} \\
\cline { 2 - 5 } & I & II & III & IV \\
\hline Dry matter & 667.4 & 728.8 & 596.8 & 634.8 \\
\hline Fat & 210.8 & 218.8 & 197.0 & 196.1 \\
\hline Protein & 174.9 & 190.7 & 153.3 & 166.4 \\
\hline Lactose & 236.9 & 268.3 & 204.5 & 229.1 \\
\hline $\begin{array}{l}\text { Fat } \\
\text { protein }\end{array}$ & 385.7 & 409.5 & 350.3 & 362.5 \\
\hline NFMS & 456.7 & 510.0 & 399.8 & 438.8 \\
\hline
\end{tabular}

The experimental data showed that increasing the percentage of the studied milk components in the milk from the cows in groups I and III did not decrease their total amount. This was explained by the lower yield from these cows, compared to the cows in groups II and IV. However, the difference between the cows in the experimental groups reduced significantly. For instance, while the difference in the milk yield values from the Holstein cows was $12.4 \%$, the total content of dry matter decreased to $8.4 \%$, of fat - to $3.7 \%$, of protein - to $8.3 \%$, and the total content of fat and protein - to $5.8 \%$. For the black-motley cows, these values were $10.9 \%, 6.0$ $\%, 0.5 \%, 7.9 \%$, and $3.4 \%$, respectively. This suggested that the absolute content of the nutrients in the lactation milk yield was the most objective set of the productive quality indicators of cows. Along with that, the crossbreed analysis showed that in the absence of a significant difference between the milk yields and the milk composition, the advantage in terms of all the milk productivity parameters was with the Holstein breed.

However, the milk characteristic as a food product and the raw material for processing may not be only limited to its composition. This requires a more in-depth assessment of its qualities, including the technological ones. In the study, the protein share increased in the milk with a high content of dry matter due to increased content of casein (Table 4). For instance, the share of casein in the total content of protein in the milk from the cows in groups I and III was $81.3 \%$ and $83.9 \%$, respectively, compared to their peers in groups II and IV $-77.5 \%$ and $81.9 \%$, the milk of which contained more whey proteins. This allowed considering the milk from the cows in groups I and III more fit for cheese-making, confirmed by the shares of casein and whey proteins (Table 4).

The milk from the cows of both breeds with a higher concentration of dry matter was characterized by an increased content of the $\alpha$ and $\beta$-fractions of casein, which are the most valuable for cheese-making. Due to these fractions, the casein content increased in the milk from the cows in groups I and III. For cheesemaking, the composition of milk whey proteins is important, mainly the content of $\alpha$-lactoalbumin and $\beta$-lactoglobulin, the increased content noted in cow milk a higher content of dry matter. With the statistical insignificance of the differences between these milk protein composition values, some advantage stayed with the black-motley breed.

The analysis of the technological characteristics of milk, such as the size and the weight of casein micelles, the content and the composition of amino acids, and the physicochemical properties of the milk (the duration of rennet clotting, the density and elasticity of the rennet clot, and the $\mathrm{Ca}$ and $\mathrm{P}$ levels) allowed considering the milk from the cows in groups I and III with the increased content of dry matter to be the most biologically complete and suitable for cheese-making. Upon comparison of the breeds, the advantage stayed with the blackmotley breed. Better technological properties of such milk predetermined the higher relative yield of cheese and lower consumption for obtaining a unit of its weight.

The results obtained after the comparative analysis of the economic efficiency of the production and sales of the milk with various compositions are shown in Table 5.

For instance, for the Holstein breed, the payment for the milk-based on the amount of milk fat per a single cow from group II would be greater by USD 13.13, compared to group I; based on the amount of dry matter, the calculated difference would be USD 3.08; for the black-motley breed, these values would be USD 0.14 and USD 1.9 , respectively. With that, the milk from the cows with a high absolute yield of dry matter (group II of the Holstein cows and group IV of the black-motley 
cows) would be estimated by USD 1.76 and USD 2.05 higher than if paid for by the content of fat alone. As a result, the payment for the milk sold by its dry matter content would allow an economy to get higher profits, and the state would not overpay for a product inferior in the nutritional and technological qualities.

\section{CONCLUSION:}

Based on the studies, it has been found that the Holstein and black-motley breeds are characterized by high milk quality, the composition of which varies depending on the milk production. For instance, in the Holstein cows with low productivity of the herd, the dry matter, fat, protein, lactose, and dry skim milk residue were higher by $4.6 \%, 9.9 \%, 4.9 \%, 0.7 \%$, and $2.3 \%$, respectively, than in the cows with higher productivity. A positive correlation has been found between the milk components. Based on the data obtained during the studies, a conclusion can be made that the milk from the cows with high dry matter content is the most suitable for making cheese. In terms of dry matter content, milk sales will allow a farm to increase revenues by USD 1.9 -3.1 .

\section{ACKNOWLEDGMENTS:}

The scientific research was performed with financial support from the Ministry of Agriculture of the Republic of Kazakhstan. The authors express their gratitude to Shagmanov Serik Zakiryanovich, the Olzha Ak Kuduk LLC farm head, who assisted in the research.

\section{ETHICAL CLEARANCE:}

Ethical permission was obtained from and agreed upon with the Academic Councils at the Kazakh Scientific Research Institute of Animal Husbandry and Forage Production (Almaty, Kazakhstan) and the Institute of Veterinary Medicine (Troitsk, Russia).

The source of funding: The research was funded by the Ministry of Agriculture of the Republic of Kazakhstan within budget program 267 "Increasing the Availability of Knowledge and Scientific Research", subprogram 101 "Programoriented Funding of Research Studies and Measures".

\section{REFERENCES:}

1. Adamczyk, K., Makulska, J., Jagusiakand, W., and Węglarz, A. (2017). Associations between strain, herd size, age at first calving, culling reason, and lifetime performance characteristics in HolsteinFriesian cows. Animal, 11(2), 327-334.

2. Babich, E. A., Kikebaev, N. A., Raketskiy, V. A., and Baysakalov, A. A. (2019). Dependence of Growth and Development of Rearing Stock in Northern Kazakhstan on the Origin of Servicing Bulls. Annals of Agri-Bio Research, 24(1), 134-138.

3. Babich, E., Nugmanov, A., Ovchinnikova, L., and Ovchinnikov, A. (2016). The efficiency of dairy herds created based on first-calf heifers of Karatomar black-andwhite interbreed cattle on northern Kazakhstan. Research Journal of Pharmaceutical, Biological, and Chemical Sciences, 7(4), 2376 - 2381.

4. Bastin, C., Loker, S., Gengler, N., Sewalem, A., and Miglior, F. (2010). Genetic relationships between body condition score and reproduction traits for Canadian Holstein and Ayrshire first-parity cows. Journal of Dairy Science, 93, 22152228.

5. Bezenko, T. I. (1983). Metodicheskie rekomendatsii po tekhnike analiza moloka i molochnykh produktov [Methodical recommendations for the milk and dairy products analysis technique]. Dubrovitsy, Russia: VIZ, 68 p.

6. Brel-Kisseleva, I. M., and Safronova, O. S. (2017). The reserves of increasing of domestic horses breeds use efficiency in the Republic of Kazakhstan. Ecology, Environment and Conservation, 23(2), 833-838.

7. Cole, J. B., Bickhart, D. M., Waurich, B., Wensch-Dorendorf, M., and Swalve, H. H. (2014). A genome-wide association study of calf birth weight in Holstein cattle using single nucleotide polymorphisms and phenotypes predicted from auxiliary traits. Journal of dairy science, 97(5), 31563172.

8. De Jong, G. (2000). Type classification in the Netherlands. Veepro Holland, pp. 20-21. 
9. Dolgosheva, E. V., Korosteleva, L. A., and Romanova, T. N. (2018). Molochnaya produktivnost i pokazateli kachestva moloka korov raznykh porod $v$ MK $\mathrm{OOO}$ "Radna" [Milk productivity and quality of the milk from cows of various breeds at Radna Milk Plant LLC]. In Collection of scientific papers for International Scientific-Practical Conference: Innovative achievements in science and technology of the AIC (pp. 4245). Kinel, Russia: RIO SGSKHA.

10. Dunin, I. M., Tyapugin, S. E., Meshcherov, R. K., Khodykov, V. P., Mescherov, S. R., and Nikulkin, N. S. (2020). Razvedenie skota golshtinskoi porody na territorii Rossiiskoi Federatsii [Breeding Holstein cattle on the territory of the Russian Federation]. Zootechny, 2, 5-8.

11. Efimova, L. V., Frolova, O. A., and Zaznobina, T. V. (2018). Vliyanie bykovproizvoditelei golshtinskoi porody na fizikokhimicheskie i tekhnologicheskie svoistva moloka docherei [The effect of Holstein stud bulls on the physicochemical and process properties of the milk of the daughters]. News of the Ulyanovsk State Agricultural Academy, 4(44), 154-157.

12. Erofeev, V. I. (2018). Molochnaya produktivnost vysokoproduktivnykh korov cherno-pestroi porody $v$ zavisimosti ot nasledstvennykh faktorov [Milk productivity of highly productive black-motley cows depending on the hereditary factors]. In Materials of the International ScientificPractical Conference: Increasing the competitiveness of livestock breeding and the tasks of staffing (pp. 67-73). Podolsk, Russia: Russian Academy of Management in Livestock.

13. Faizullin, P. V., and Kharlan, S. Y. (2019). Tekhnologicheskie svoistva moloka korov raznykh porod [Process properties of the milk from cows of various breeds]. Youth and Science, 5-6, 59.

14. Firsova, E. V., and Kartashova, A. P. (2019). Golshtinskaya poroda v Rossiiskoi Federatsii, sovremennoe sostoyanie i perspektivy razvitiya [The Holstein breed in the Russian Federation, its current state and development prospects]. Genetics and animal breeding, 1, 62-69.

15. Gagloev, A. C., Negreeva, A. N., Gagloeva, T. N., and Skobeev, A.D. (2017). Sostav i svoistva moloka korov cherno-pestroi porody razlichnogo proiskhozhdeniya Composition and properties of the milk from black-motley cows of various origin]. In: V.A. Solopov (Ed.), Modern technologies in animal husbandry: issues and solutions. Materials of the International Scientific-Practical Conference (pp. 132-136). Michurinsk, Russia: Michurinsk State Agrarian University.

16. Holroyd, R.G., Doogan, V.J., De Faveri, J., Fordyce, G., McGowan, M.R., Bertram, J.D., Vankan, D.M., Fitzpatrick, L.A., Jayawardhana, G.A., Miller, R.G. (2002). Bull selection and use in northern Australia. 4. Calf output and predictors of fertility of bulls in multiple-sire herds. Animal Reproduction Science, 71, 67-79.

17. Izhboldina, S. N., and Nikolaeva, S. V. (2013). Molochnaya produktivnost korov airshirskoi, golshtinskoi porod v usloviyakh Udmurtskoi respubliki [Milk productivity of the Ayrshire and Holstein cows in the conditions of the Udmurt Republic]. Scientific notes of the Bauman Kazan State Academy of Veterinary Medicine, 213, 100-103.

18. Kakhikalo, V. G. (Ed.). (2009). Selektsionnye i tekhnologicheskie metody povysheniya produktivnosti chernopestrogo skota Zauralya [Breeding and technological methods of increasing the productivity of black-motley cattle in the Trans-Urals]. Kurgan, Russia: The Kurgan State Agricultural Academy, 275 p.

19. Karamaev, S. V., Karamaeva, A. S., and Soboleva, N. V. (2016). Tekhnologicheskie svoistva moloka korov molochnykh porod $v$ zavisimosti ot sezona otela [Process properties of the milk from dairy cows depending on the calving season]. Kinel, Russia: Samara State Agricultural Academy, $181 \mathrm{p}$.

20. Karamaeva, A. S., Soboleva, N. V., and Karamaev, S. V. (2018). Vliyanie porody na syroprigodnost moloka i kachestvo syra [The effect of the breed on milk suitability for making cheese and cheese quality]. Dairy and beef cattle breeding, 5, 34-38.

21. Katmakov, P. S., Gavrilenko, V. P., Bushov, A. V., and Prokofiev, A. N. (2019). Selektsionno-plemennaya rabota $v$ molochnom skotovodstve [Breeding work in dairy cattle breeding]. Ul'yanovsk, 
Russia: Stolypin Ulyanovsk State Agrarian University, $167 \mathrm{p}$.

22. Khromova, L. G., and Manzhurin, O. A. (2018). Produktivnye $i$ biologicheskie osobennosti korov molochnykh porod $v$ usloviyakh intensivnoi tekhnologii [Productive and biological characteristics of dairy cows in the conditions of intensive technology]. Voronezh, Russia: Emperor Peter I Voronezh SAU, 153 p.

23. Kuznetsov, V. M., and Ireykina, R. P. (2017). Osobennosti zagotovki kormov i sposoby uluchsheniya kormovykh ratsionov dlya laktiruyushchikh korov sakhalinskoi populyatsii golshtinskoi porody [Peculiarities of fodder preparation and the methods of improving diets for lactating cows of the Sakhalin Holstein population]. In: V.A. Chuvilina (Ed.), Collection of scientific articles: Scientific support, features and perspectives of agriculture development in the Far East region (pp. 60-72). Yuzhno-Sakhalinsk, Russia: Poligraficheskaya kompaniya "Kano".

24. Lakin, G. F. (1990). Biometriya [Biometrics]: Textbook. A guide for biological specialities in higher education institutions. 4th ed., revised and amended. Moscow, Russia: Vysshaya Shkola, 352 p.

25. Mkrtchyan, G. V., Bakai, A. V., and Bakai, I. R. (2020). Nasledovanie belkovomolochnosti u krupnogo rogatogo skota raznoi selektsii [The inheritance of protein milk in cattle of various breeding origins]. Agricultural science, 2, 36-38.

26. Morozova, N. I., Musaeva, F. A., and Morozova, O. A. (2016). Sravnitelnaya otsenka molochnoi produktivnosti korov golshtinskoi porody i cherno-pestroi pri kruglogodovom stoilovom soderzhanii [A comparative assessment of Holstein and black-motley cows' milk productivity with year-round keeping in stalls]. News of the Michurinsky State Agrarian University, 3, 66-69.

27. Nemtseva, E. Y., and Ignatieva, N. L. (2020). Planirovanie selektsionnoplemennoi raboty $v$ molochnom skotovodstve [Planning of breeding work in dairy cattle breeding]. In Materials of the All-Russian scientific-practical conference with international participants, held at
Cheboksary, February 20, 2020 (pp. 7380).

28. Paderina, R. V. (2020). Lineinaya otsenka eksterera i ee svyaz s molochnoi produktivnostyu [Linear assessment of the exterior and its relationship with the milk productivity]. In: L.P. Blinkova (Ed.), Innovative paradigm in the development of natural sciences (pp. 26-37). Petrozavodsk, Russia: International Center for Scientific Partnership "New Science".

29. Pavlov, S. D. (2019). Molochnaya produktivnost korov golshtinirovannoi cherno-pestroi porody [Milk productivity of cows of the Holsteinized black-motley breed]. In: A.B. Kudzaev (Resp. Ed.), Scientific works of students of the Gorsky State Agrarian University (pp. 181-183). Vladikavkaz, Russia: Gorsk State Agrarian University.

30. Pimentel, E. C. G., Erbe, M., Knig, S., and Simianer, H. (2011). Genome partitioning of genetic variation for milk production and composition traits in Holstein cattle. Front. Livest. Genomics., 2, 19.

31. Pustotina, G. F., and Pustotina, N. V. (2016). Proizvodstvo moloka pri ratsionalnom ispolzovanii geneticheskikh resursov otechestvennykh porod skota [Milk production with the rational use of the genetic resources of domestic cattle breeds]. News of the Orenburg State Agrarian University, 3(59), 133-135.

32. Safronova, O. S., Babich, E. A., Ovchinnikova, L. Y., and Ovchinnikov, A. A. (2017). Polymorphism of Kappa-Casein, Somatotropin, Beta-Lactoglobulin, Prolactin, and Thyreoglobulin Genes of Black and White Cattle of North Kazakhstan. Journal of Pharmaceutical Sciences and Research, India, 9(5), 568573.

33. Samusenko, L. D., and Khimicheva, S. N. (2018). Kachestvo i bezopasnost moloka: osnova prodovolstvennoi bezopasnosti [Milk quality and safety: the bases of food safety]. News of Agrarian Science, 1(70), 46-51.

34. Shishkina, T. V., Nikishova, N. V., and Naumov, A. A. (2017). Vliyanie krovnosti po golshtinskoi porode na molochnuyu produktivnost i prodolzhitelnost khozyaistvennogo ispolzovaniya korov 
cherno-pestroi porody [The effect of blood relationship to the Holstein breed on the milk productivity and the duration of economic use of black-motley cows]. Chief zootechnician, 12, 22-26.

35. Shushpanova, K. A., and Tatarkina, N. I. (2020). Produktivnost korov golshtinskoi porody [Productivity of Holstein cows]. News of the Kurgan State Agricultural Academy, 2(34), 44-47.

36. Tatarkina, N. I., and Belenkaya, A. E. (2017). Prodolzhitelnost produktivnogo ispolzovaniya korov golshtinskoi porody $\mathrm{v}$ usloviyakh Severnogo Zauralya [The duration of productive use of Holstein cows in the conditions of the Northern TransUrals]. Bulletin of the State Agrarian University of the Northern Trans-Urals, 1 , 73-77.

37. Tomilin, Y. K., Zelenkov, P. I., and Tomilin, V. K. (2012). Produktivnost i perspektiva ispolzovaniya germanskikh golshtinofrizov dlya uluchsheniya golshtinizirovannogo cherno-pestrogo skota otechestvennoi selektsii [Productivity and the prospects of using German Holstein Friesian cattle for improving
Holsteinized black-motley cattle of domestic breeding]. Scientific Journal of the KubSAU, 76, 742-753.

38. Tumov, A. A. (2018). Produktivnye osobennosti korov golshtinskoi porody raznoi selektsii [Productive features of Holstein cows of various breeding origin]. Bulletin of the Altai SAU, 3(161), 101-105.

39. Wang, Y., Segelke, D., Emmerling, R., Bennewitz, J., and Wellman, R. (2017). Long - Term Impact of Optimum Contribution Selection Strategies on Local Livestock Breeds with Historical Introgression Using the Example of German Angler Cattle. G3: Genes, Genomes, Genetics, 7(12), 4009-4018.

40. Yesbolova, A., and Maciejczcak, M. (2012). Livestock production in Kazakhstan: situation, problems, and possible solutions. In: P. Bórawski (Ed.), Multifunctional development of rural areas. International experience, Vol. 2 (pp. 4350). Ostrołęka, Poland: Publishing House of the University of Economics and Social Sciences in Ostrołęka.

Table 1. Milk productivity and composition

\begin{tabular}{|c|c|c|c|c|}
\hline \multirow[t]{3}{*}{ Indicator } & \multicolumn{2}{|c|}{ The Holstein breed } & \multicolumn{2}{|c|}{ The black-motley breed } \\
\hline & \multicolumn{4}{|l|}{ Group } \\
\hline & I & II & III & IV \\
\hline The milk yield, $\mathrm{kg}$ & $5,167 \pm 112$ & $5,901 \pm 154$ & $4,469 \pm 143$ & $5,018 \pm 128$ \\
\hline Dry matter, \% & $12.92 \pm 0.84$ & $12.35 \pm 0.77$ & $13.35 \pm 0.73$ & $12.65 \pm 0.62$ \\
\hline Fat, \% & $4.08 \pm 0.02$ & $3.71 \pm 0.01$ & $4.41 \pm 0.03$ & $3.91 \pm 0.02$ \\
\hline Protein, \% & $3.39 \pm 0.03$ & $3.23 \pm 0.01$ & $3.43 \pm 0.04$ & $3.32 \pm 0.02$ \\
\hline Lactose, $\%$ & $4.58 \pm 0.82$ & $4.55 \pm 0.58$ & $4.58 \pm 0.68$ & $4.56 \pm 0.71$ \\
\hline Fat + protein, $\%$ & $7.47 \pm 0.23$ & $6.94 \pm 0.25$ & $7.84 \pm 0.32$ & $7.23 \pm 0.28$ \\
\hline NFMS, \% & $8.84 \pm 0.62$ & $8.64 \pm 0.53$ & $8.94 \pm 0.64$ & $8.74 \pm 0.50$ \\
\hline
\end{tabular}


Table 2. The correlation between the milk yield and milk composition

\begin{tabular}{|c|c|c|c|c|}
\hline \multirow[t]{2}{*}{ Indicator } & \multicolumn{4}{|l|}{ Group } \\
\hline & $\mathrm{I}$ & II & III & IV \\
\hline Milk yield vs. dry matter & -0.42 & $-0.74^{*}$ & -0.30 & -0.51 \\
\hline Fat vs. dry matter & +0.86 & $+0.90^{* * *}$ & $+0.84^{* *}$ & $+0.84^{* *}$ \\
\hline Protein vs. dry matter & $+0.99^{* * *}$ & $+0.84^{\star *}$ & +0.32 & $+0.65^{*}$ \\
\hline Lactose vs. dry matter & +0.20 & +0.50 & +0.17 & $+0.66^{* *}$ \\
\hline Fat + protein vs. dry matter & $+0.96^{* * *}$ & $+0.97^{* * *}$ & $+0.90^{* * *}$ & $+0.96^{* * *}$ \\
\hline NFMS vs. dry matter & $+0.85^{\star *}$ & $+0.79^{* *}$ & +0.40 & $+0.82^{* *}$ \\
\hline Milk yield vs. fat & -0.30 & $-0.63^{*}$ & -0.43 & -0.13 \\
\hline Protein vs. fat & $+0.80^{* *}$ & +0.59 & -0.02 & +0.23 \\
\hline Lactose vs. fat & -0.24 & +0.14 & -0.19 & +0.40 \\
\hline Fat + protein vs. fat & $+0.96^{* * *}$ & $+0.96^{* * *}$ & $+0.95^{\star * *}$ & $+0.87^{* \star *}$ \\
\hline NFMS vs fat & +0.46 & +0.45 & -0.17 & +0.37 \\
\hline Milk yield vs. protein & -0.36 & -0.64 & -0.12 & $-0.79^{* *}$ \\
\hline Lactose vs. protein & +0.22 & +0.53 & -0.12 & +0.24 \\
\hline Fat + protein vs. protein & $+0.94^{* * *}$ & $+0.79 * *$ & +0.29 & $+0.68^{*}$ \\
\hline NFMS vs. protein & $+0.88^{* * *}$ & $+0.91^{* * *}$ & +0.62 & $+0.86^{* *}$ \\
\hline Milk yield vs. lactose & -0.15 & -0.45 & - & -0.26 \\
\hline Fat + protein vs. lactose & -0.04 & +0.29 & -0.18 & +0.42 \\
\hline NFMS vs. lactose & +0.59 & $+0.83^{* *}$ & $+0.63^{*}$ & $+0.70^{*}$ \\
\hline Milk yield vs. fat + protein & -0.34 & $-0.70^{*}$ & -0.45 & -0.50 \\
\hline NFMS vs. fat + protein & +0.69 & $+0.65^{*}$ & +0.03 & $+0.71^{*}$ \\
\hline Milk yield vs. NFMS & -0.42 & $-0.63^{*}$ & +0.18 & $-0.72^{*}$ \\
\hline
\end{tabular}

Table 4: The composition of protein in the milk from the Holstein and black-motley cows, \%

\begin{tabular}{lllll}
\hline Indicator & \multicolumn{2}{l}{$\begin{array}{l}\text { The Holstein } \\
\text { breed }\end{array}$} & $\begin{array}{l}\text { The black-motley } \\
\text { breed }\end{array}$ \\
\cline { 2 - 5 } & Group & & & \\
\cline { 2 - 5 } & I & II & III & IV \\
\hline Total protein, total & 3.27 & 3.25 & 3.35 & 3.31 \\
\hline Including: & & & & \\
casein & 2.66 & 2.52 & 2.81 & 2.71 \\
whey proteins & 0.61 & 0.73 & 0.54 & 0.60 \\
\hline \% of total protein: & & & & \\
casein & 81.3 & 77.5 & 83.9 & 81.9 \\
whey proteins & 18.7 & 22.5 & 16.1 & 18.1 \\
\hline Casein: & & & & \\
$\alpha-$ & 44.38 & 44.03 & 44.89 & 44.62 \\
$\beta-$ & 50.51 & 50.34 & 51.51 & 50.97 \\
$\gamma-$ & 5.11 & 5.63 & 3.60 & 4.41 \\
\hline Whey proteins: & & & & \\
Immune globulins & 19.91 & 22.45 & 19.59 & 21.27 \\
$\alpha-l a c t o a l b u m i n$ & 20.45 & 18.74 & 18.30 & 17.33 \\
$\beta-l a c t o g l o b u l i n$ & 57.35 & 56.11 & 59.19 & 57.67 \\
serum albumin & 2.29 & 2.70 & 2.92 & 3.73 \\
\hline
\end{tabular}


Table 5: The economic efficiency of milk production and sales

\begin{tabular}{|c|c|c|c|c|}
\hline \multirow[t]{3}{*}{ Indicator } & \multicolumn{2}{|c|}{$\begin{array}{c}\text { The Holstein } \\
\text { breed }\end{array}$} & \multicolumn{2}{|c|}{$\begin{array}{l}\text { The black- } \\
\text { motley breed }\end{array}$} \\
\hline & \multicolumn{4}{|c|}{ Group } \\
\hline & I & II & III & IV \\
\hline Cost of milk per lactation, USD & 19.23 & 21.96 & 18.63 & 20.92 \\
\hline Sales cost of milk with the basic fat content, USD & 31.93 & 31.79 & 31.93 & 31.78 \\
\hline Profit from milk sales in terms of fat, USD & 14.93 & 13.51 & 13.30 & 10.87 \\
\hline Sales cost of milk in terms of nonfat solids, USD & 33.39 & 36.46 & 29.85 & 31.76 \\
\hline Profit from milk sales in terms of nonfat solids, USD & 14.15 & 14.49 & 11.23 & 10.84 \\
\hline
\end{tabular}

Periódico Tchê Química. ISSN 2179-0302. (2020); vol.17 ( $\left.n^{\circ} 36\right)$

Downloaded from www.periodico.tchequimica.com

This article is licensed under a Creative Commons Attribution 4.0 (CC BY 4.0) International License, which permits use, sharing, adaptation, distribution, and reproduction in any medium or format, as long as you give appropriate credit to the original author(s) and the source, provide a link to the Creative Commons license, and indicate if cha Creative Commons license unless indicated otherwise in a credit line to the material . If material is not included in the article's Creative Commons license and your intended use is not permitted by statutory regulation or exceeds the permitted use, you will need to obtain permission directly from the copyright holder. To view a copy of this license, visit http://creativecommons. org/licenses/by/4.0/. 